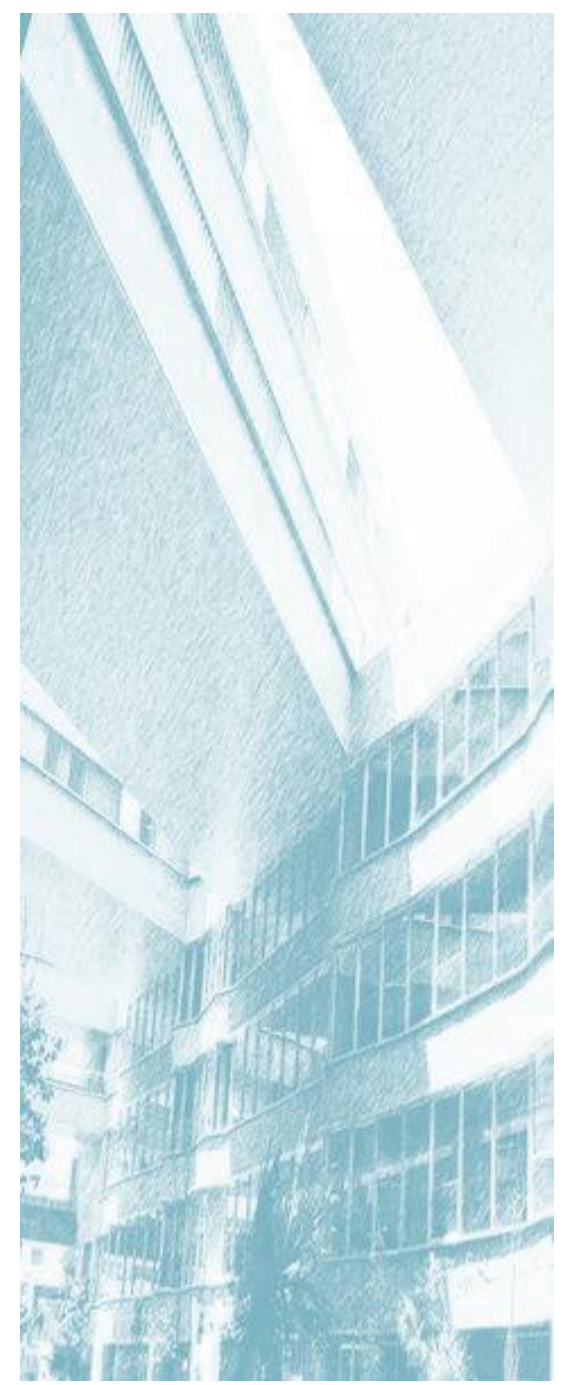


Strategies of action: improving employability 


\title{
STRATEGIES OF ACTION: IMPROVING EMPLOYABILITY
}

\author{
Barbara Merrill \\ University of Warwick, UK
}

Fecha de recepción: 14/11/2014

Fecha de aceptación: 20/01/2015

\section{INTRODUCTION}

Higher education institutions across Europe are transforming, albeit reluctantly in some cases, as a result of changing state/university relationships, economic and social changes, internationalisation and globalisation. Increasingly they have been subject to the influences of marketisation and neo-liberalism. Externally universities are also now engaging with other sites of knowledge producers while internally new and diverse student groups are entering (Scott, 2005). Traditional universities are also under pressure to break down the ivory tower image and engage in partnerships with employers and local communities to the extent that according to Barnett: 'Institutional boundaries become less tight as interrelationships with the wider society grow' (Barnett, 2003: 27). While some systems remain elite the system as a whole has become a mass-based one (Scott, 2001, Osborne, 2003) opening up opportunities for widening participation and access for groups who never previously entered higher education. As a result the student population has become more diverse by age, class, gender, ethnicity and disability. Higher education, therefore, has an important role to play in providing lifelong learning opportunities, including within this employability skills for the labour market.

Expansion of European higher education has, therefore, enabled a higher percentage of people to enter and participate at degree level (OECD, 2001). For Redmond (2006) expansion is associated with the need for a more highly educated workforce to enable Europe to compete in the global and knowledge-based economy. Between 19982006 the average participation rate in $\mathrm{HE}$ increased by $25 \%$ while in some countries, such as Poland, it increased by $90 \%$ indicating a move towards more knowledge-based societies. The range of programmes offered has also expanded so that adults can participate on full or part-time degree programmes. At postgraduate level there has been a growth in short Continual Professional Development courses as well as courses focusing specifically on issues of employability, particularly at undergraduate level. The labour market is also changing. Between 2010 and 2020 the proportion of jobs requiring academic skills will rise form $20 \%$ to $34 \%$, while 
low skilled jobs will decrease from $23 \%$ to $18 \%$ during the same period (EC Rethinking Education, 2010).

The issue of employability is a central policy concern of the EU, national governments, and higher education institutions and is also a key goal of the Bologna process (The European Higher Education, 2012: Bologna Implementation Report). The Bologna Declaration, established in 1999 has led to the creation of a European Higher Education Area with the aim of creating a more common system of higher education across Europe while still respecting national and cultural diversity. According to the Confederation of European Union Rectors' Conferences and the Association of European Universities:

The process originated from the recognition that in spite of their valuable differences, European higher education systems are facing common internal and external challenges related to the growth and diversification of higher education, the employability of graduates, the shortage of skills in key areas, the expansion of private and transnational education etc. (p3).

The determination to change the nature of universities within the European Union was further enhanced at the Leuven and Louvain la Neuve Communiguế in 2009. It stressed the need for universities to 'equip students with the advanced knowledge, skills, competences they need throughout their professional lives' (2009: 2). To achieve this a closer partnership is advocated between universities, employers and governments. Economic changes at national, European and global levels, as well as increased economic competiveness and the move towards knowledge-based societies (Castells, 2001) has thus created a closer relationship between higher education and the labour market (Morley, 2001). Yet despite this according to Little (2003) conceptual and contextual differences exist between universities and industry which makes it difficult to assess whether graduates are meeting the needs of employers. This has changed the fundamental nature and purpose of the university and critics point out that this situation entails a shift away from the social purpose of a university to what Gumport (2000) calls an industry.

In the late 1960s and 1970s moves towards involvement by industry in universities was opposed by academia. In my own university E.P. Thompson, an eminent historian writing about the English working class and professor at Warwick at that time, wrote a book in 1970 called Warwick University Limited in which he opposed the intrusion of industry into the affairs of the University. And maybe there is a need to ensure that there is a balance between the social, educational and economic 
function of a university. The external economic and social forces which have led to transforming the purpose and nature of the university have in turn impacted upon the perspectives and expectations which students bring with them to their undergraduate studies. For many undergraduate students studying for a degree is not just about learning for learning sake's and following a particular discipline in depth but rather as Tomlinson points out: 'It now appears no longer enough just to be a graduate, but instead an employable graduate'(2012: 25). Higher education is now viewed by students, as Tomlinson (2012) asserts as being an investment in their future lives in the labour market. They realise that it is a competitive world out there and that to get the best graduate jobs they need to offer more to employers than just their degree qualification. This process also puts increasing pressure on students to engage in activities other than their degree work in order to gain extra credentials to help them in the graduate labour market. Society, as Beck (1992) points out has become an individualised and risky business.

Higher education institutions have also changed and adapted to the changing competitive global market by embracing the notion of employability and the need to engage with and assist students, at both undergraduate and postgraduate levels, to become employable through more vocational modules, department and institutional initiatives. As a result Careers Services have broadened their agenda to include specific activities aimed at helping students to become more employable. At my own university we now have a person with the job title of Director of Careers and Student Employability. Universities in England now have to have an employability statement after being requested to do so by the Higher Education and funding Council for England (HEFCE) in 2010.

\section{DEFINING EMPLOYABILITY}

Higher education is, therefore, now deemed to be critical in developing a nation's and Europe's economic development. It is argued that a degree provides graduates with credentials which are essential for developing a knowledge-based society. But what do we mean by employability? I just want to explore this a little bit. Traditionally just having a degree - whether it was in the humanities or sciences - was seen as good enough for obtaining a good job but as outlined above times have changed. In looking at relevant literature and policy documents there does not appear to be a consensus as to its meaning. At a conceptual level there are also differences in approaches. As Tymon asserts: 'employability is complex and multidimensional' (2013: 842). This is partly because the meaning of employability is perceived 
differently by the different actors involved: students, higher education institutions and employers (Hugh-Jones et al., 2006) and even differently within those groups. In brief employability can be seen as preparing graduates for employment in the labour market at a level which reflects their qualifications and intellect. Some authors view employability as simply equipping students with the appropriate skills but there is a need to go beyond just a skills definition. Yorke's definition has a more helpful and holistic understanding as he defines employability as:

a set of achievements, skills, understandings and personal attributes, that make graduates more likely to gain employment and be successful in their chosen occupations, which benefits themselves, the workforce, the community and the economy (2004: 210).

However, Brown, Hesketh and Williams (2002) are critical of defining employability from an individualistic perspective as they stress that 'employability is primarily determined by the labour market rather than the capabilities of individuals (2002: 9). Instead they argue for a definition which takes into account the 'duality of employability'. This encompasses an 'absolute' dimension and refers to graduates having the appropriate skills, knowledge and commitment. The second dimension they describe as being 'relative' and relates to what is happening in the labour market in terms of supply and demand as a graduate may have the appropriate skills and competences but there may not be graduate jobs available. In such a situation graduates may be employable but not have a job. For them employability is defined 'as the relative chances of finding and maintaining different kinds of employment' (Brown et. al, 2002: 11). Their dual definition is important as it recognises that the individual should not always be blamed for not finding a job or a job at an appropriate level as structural factors also have an impact on the graduate labour market.

There is still concern amongst employers that graduates lack the appropriate skills on entry into graduate employment (Cumming, 2010). Archer and Davison's (2008) looking at employers' perspectives illuminated that they increasingly valued key soft skills such as communication, team working and integrity as much as knowledge/subject skills as a result of work becoming more customer focused.

Most of the definitions do appear to focus on the individual student but as Brown et al (2002) assert a student does not exist in a vacuum but interacts with others and also institutions in particular contexts. I would, therefore, stress that any definition of employability 
needs to take into account the micro, meso and macro levels. In a similar way to Brown's et al (2002) approach I would argue the need for looking at the interaction between structure and agency. For example at certain times a person is able to use their agency - in this case obtain a graduate level job. At other times an individual may use their agency but the structural factors are too strong as there are few or no relevant jobs in the labour market. In such a situation there is a mismatch as they may have to take a job which is below graduate level to avoid being unemployed. Employability and securing a job in the graduate labour market has also to do, and drawing on Bourdieu's work, with the levels of cultural, social and economic capitals a student brings with them to the university and develops while they are they. These concepts will be explored later.

Employability is also about managing the transition from learning to earning, from education to the world of work, although for adult students this may not be the first transition into work. Students feel increasingly the need to be 'employable' and to prepare themselves for firstly finding a suitable job and ensuring that they are capable of doing that job (Clarke, 2008) by assembling a portfolio of skills, knowledge and experiences. The argument goes that in post-industrial societies a job is no longer for life and research by Moreau and Leathwood (2006) indicates that graduates are expecting the labour market to be uncertain and unpredictable. Learning to be employable and flexible in the labour market will, for many, not be confined to something you prepare for in universities but will continue throughout working lives to enable them to prepare for future career transitions. Graduates need to be lifelong learners and engage in professional development throughout their lives if they are going to survive and thrive in the labour market at a particular level.

\section{CONCEPTUAL AND THEORETICAL APPROACHES}

Before exploring strategies and actions which can be undertaken by higher education institutions to enhance and support the employability of their students I want to look at some conceptual and theoretical approaches - some critically - as I feel that theory helps to inform practice.

As Tomlinson $(2012,2010)$ critically asserts higher education policy has largely been dominated by human capital theory. Human capital theory views a university education as being an investment for the individual, the university, and society's economy. In this framework universities provide and match students with the skills and credentials 
they need to engage with the labour market to fill the jobs which only those with the highest qualifications and skills can take. For individual students it is also an investment as the 'promise' is that in return they will receive employment in the highest paid jobs. At societal level their human capital is contributing to a nation's knowledge economy in times of a competitive global market. In the UK students have to now make a financial investment in their studies as they have to pay fees - $\$ 900$ (11, 300 euros) a year and there are signs that his may rise so being employable becomes all the more imperative if they are to avoid future debt. Like Tomlinson I am critical of the human capital theory as it promotes an individualistic competitive approach with an emphasis on skills acquisition. Skills are discussed in quantifiable terms and hence uses a rational, instrumental, technical and utilitarian approach. Leonard refers to this as the 'project of masculinity' (200: 181) as the human, social side is absent. In terms of teaching it produces 'narrow and instrumental teaching practices' (2006: 14) according to Hyslop-Marginson and Sears. They go on to argue that such 'a neoliberal education policy reduces learning to a discursive ideological apparatus that encourages student conformity to the market economy (2006: 14).

Importantly it also ignores issues of inequality such as class, gender and race which increasingly characterise the student population in a mass based system which results in less opportunities in the job market for some students. On a different level it obscures, as Blackmore and Sachs point out, the academic, social and educational benefits which studying in university can bring as the focus is on employability and market needs (Blackmore \& Sachs, 2003). For Lave and Wenger (1991) the emphasis on skills and the transferability of skills omits to take into account the social context of learning. In a European project I co-ordinated on access, retention and withdrawal of non-traditional students (younger and adult) in higher education in Europe we found, from listening to students' stories that even those who left without completing said that they had gained benefits from learning which were educational, and social and which had led to self-development. Yet in the eyes of higher education institutions and policy-makers such students are 'failures' and an economic costing as they have not invested their human capital in the graduate labour market and economy.

Critics of human capital theory and skills approaches to graduate employability and higher education have turned to a more social constructive approach or as Holmes (2013) calls it a 'social postitioning' perspective. This draws heavily on the work of Pierre Bourdieu and his concepts of capitals, habitus and field and has been used in relation to employability by, for example, Brown and Scase (1994), Kalfa and Taksa (2013) and Tomlinson (2008). Bourdieu (2005) stresses the need to look at 
social behaviour within a particular context. His work on education with Passeron (1977) in general and higher education in his study Homo Academicus (1990) looks at how the education system is a form of cultural reproduction.

Bourdieu's work on social class is useful in looking at the experiences of working-class and non-traditional students in higher education and how their habitus affects their chances of employability in the labour market. - Our RANLHE study of non-traditional students and access and retention in HE also used Bourdieu's work in making sense of their experiences. Bourdieu draws on Marx in his analysis of class in seeing class in relation to the means of production and in looking at how dominant classes maintain their power and the reproduction of class. However, he differs from Marx as he also draws on Weber in looking at notions of lifestyle. Class, for Bourdieu, is based on four different forms of capital (cultural, economic, social and symbolic) which people inherit through socialisation in social spaces such as the family. Different classes, therefore, have different levels of capital. For example, working-class adult students arrive at university with a different cultural capital to that of the younger middle class students as a result of their family background and initial educational experiences. Students, therefore, because of class inequality and also inequalities of gender, age and race, do not start the 'employability pathway' on a level playing field.

The different levels of capital produce a certain class habitus which structurally locates a person in society or identifies "a sense of one's place' but also a 'sense of the place of others" (Bourdieu, 1989: 19). Habitus also endows a person with dispositions (attitudes, thoughts feelings, practice) which shape the way a person acts in relation to others and society. Habitus is useful in looking at the biographies of nontraditional students as it links class and identity. Bourdieu's work on class and habitus has been criticised for being too deterministic as he outlines how classes are socially reproduced. However, the concept of habitus does make a link between objectivity and subjectivity and hence the possibility for individual or collective change through agency. While Bourdieu stated that; 'We can always say that individuals make choices, as long as we do not forget that they do not choose the principles of these choices' (Bourdieu in Wacquant, 1989: 50). He later asserted that:

Habitus is not the fate that some people read into it. Being the product of history, it is an open system of dispositions that is constantly affected by them in a way that either reinforces or modifies its structures (Bourdieu in Bourdieu and Wacquant, 1992: 133). 


\section{INEQUALITIES AND EMPLOYABILITY}

My research interests focuses on the experiences of non-traditional students in higher education and inequalities such as class and gender. I would, therefore, like to centre largely on this group in relation to employability and strategic actions for, as Tomlinson (2008) points out there is a lack of research in relation to this group in relation to employability. In contrast there is a large body of research which looks at the access and learning experiences of such students in higher education.

There is increasing evidence that graduate employability is a problem across Europe (Edvardsson Stiwne \& Gaio Alves, 2010, Tomlinson, 2008). Research indicates that particular groups of students, such as non-traditional students, are more affected in terms of graduateness than other students (Brown \& Hesketh, 2004, Reay et al 2006). Non-traditional students are taking a longer transition period than 'traditional' students to gain employment and when they do it is often at a lower and less meaningful level than graduate level. Such students, therefore, experience a mismatch between higher education qualifications and the demand of the labour market. In defining a nontraditional student I draw on our European RANLHE project. By nontraditional we mean students who are under-represented in higher education and whose participation in higher education is constrained by structural factors. This includes, for example, students from particular minority ethnic groups, living in what are described as low participation areas, working class women and men, adult students, students with disabilities and increasingly EU migrants as well as asylum seekers/refugees.

Undertaking a degree as an adult or as a working class younger student in an elite university is a risky business (Barnett, 2007, Reay 2003) as there is no guarantee of obtaining a well-paid job or even a job at all after completing a degree. Age also comes into play here as employers are more reluctant to employ older graduates. There is also emerging evidence to indicate that there is a growing north-south divide in Europe in relation to this issue due to the economic crisis. Consequently the pattern of employability is different across countries (EC Employment and Social Developments 2012). For example, in Germany the employment rate of graduates is high while in Portugal there is hardly any difference in the unemployment rates between those with a degree and those with low level skills. Here in Spain it is also difficult for graduates to gain employment. In many countries there is a lack of opportunities 
and pathways from vocational training into higher education to increase their employability and job mobility. This situation again affects largely non-traditional students by limiting their study choices (OECD, 2012).

Drawing on Bourdieu's work working class students (younger and older) have a different habitus and cultural capital to middle class students and to the habitus and culture of universities, particularly elite universities. As Brown and Scase (1994) point out those from privileged backgrounds have higher levels of cultural capital which puts them at an advantage in the labour market. They are also more likely to possess extensive social capital and networks which helps in terms of links and connections to employers. Brown et al assert:

The idea of cultural capital has been helpful in understanding how individuals and families from middle class backgrounds are able to 'capitalise' on their cultural assets in ways that those from disadvantaged backgrounds are not... When employers reject candidates as unsuitable it could be argued that they are being rejected for lacking 'cultural' capital. There is absolutely no doubt that this happens when people are seen to have the wrong accent, dress inappropriately at interview, or do not know the rules of the game when candidates are invited to a formal dinner to meet company employees (2002: 28).

Recent research indicates that employers are increasingly looking for social/ soft skills just as much as hard skills when employing graduates. They explain that this situation happens because those who make the decision about who to appoint come from a similar cultural background. Brown et al (2002), therefore, emphasise that the strategy of how 'students, prepare, package and present 'themselves' in the recruitment process' (2002: 28) is critical. They argue that 'the management of employability is largely a question of how cultural capital is translated into personal capital' (2002: 28). Research indicates that working class students are aware and conscious of class differences at university (Reay, 2003, Merrill, 2012) so that some as in Bourdieu's term feel like 'fish out of water'. Tomlinson argues that:

In terms of social class influences on graduate labour market orientations, this is likely to work in both intuitive and reflexive ways. Studies of non-traditional students show that while they make 'natural, intuitive choices based on the logic of their class background, they are also highly conscious that the labour market entails sets of middle-class values and rules that potentially alienate them (2012: 423). 
This is certainly the case in the UK as the class system is deeply embedded within society and there is evidence that those from privileged backgrounds who have been to private (public) schools and then Oxbridge obtain the top jobs in UK society. This process is often seen as being part of 'the old boys network' and it is also a gendered and raced thing so that if you are a female or black it is harder to get the top graduate jobs. A recent study by the Institute of Fiscal Studies, UK, indicates that those graduates who went to a private school earn at least $£ 4,500$ (5,660 euros) more than graduates who went to state schools. Clare Crawford, Professor of Economics at the University of Warwick and a researcher with the Institute of Fiscal Studies stated in a press release that:

Our research shows that even amongst those who succeed in obtaining a degree, family background - and in particular the type of school they went to - continues to influence their success in the work place.

Research by Smith et al (2011) highlighted that the class of degree, subject studied, prior qualifications and social class background are key factors in determining whether a graduate is likely to be unemployed six months after leaving university.

Education is often viewed as a pathway to social mobility and universities as an institution which acts as a leveller. However, mass high education, while widening participation allowing more people to enter $\mathrm{HE}$, it has also led to a tiered system. This has resulted in a contradictory situation whereby there is now an over-supply of graduates but not enough graduate level jobs. In the UK this has produced a big binary divide between the 'traditional' universities and the post 1992 universities. And within the traditional universities there is a hierarchy between the elite universities (Russell Group) and those not in this group. Employers favour graduates from the traditional universities and the Russell Group in particular. The post 1992 universities have a higher percentage of students from more diverse backgrounds by class, ethnicity and age. These issues of inequality need to be taken into account and challenged when developing employability strategies. Adult students are also limited in their labour market choices as they are tied, because of families, to a specific geographical locality. Higher education institutions need to work collaboratively with local companies and organisations to encourage them to employ local adult graduates as they have a lot to offer to the local economy.

Universities are transitional spaces in the biographies of for both younger and adult students. It offers a place for the re-working of 
identities and for thinking about who they want to become in the future. For younger students it is about moving from school and dependency to adulthood and independence and the start of a life of work. For many adult students it may offer the potential for a career transition and mobility.

So what can universities do to improve the employability of its graduates, and in particular, that of non-traditional students? The Confederation of British Industry stated in their report Boosting Employability Skills (2012) that 'businesses want graduates who not only add value but who have the skills to help transform their organisation in the face of continuous and rapid economic and technological change'.

\section{MOVING TO STRATEGIES}

As a biographical researcher I would like to bring a little bit of my story into this discussion to illustrate the changes which have taken place over time in relation to higher education and the idea of employability.

I did my degree - History/Sociology at Warwick University 19731976. In those days in the UK doing a degree was about studying a particular subject and discipline in order to learn academic knowledge and had nothing to do with employability or vocation. Indeed for those of us studying the social sciences and arts and humanities employment and finding a job was something which I and my friends did not think about or consider until we had almost completed our degree. You just assumed that having a degree was good enough in itself to get a job at graduate level and a good job. I think that it was also related to the particular historical and cultural times of the 70s in the UK when many of us were influenced by and adherers of Marxism, feminism and hippy culture challenging capitalist and the work ethic. How times have changed. Students are now more serious about their work and at the same time instrumental and focused about doing a degree to get a good a good job. Individuals are left increasingly to develop the skills and competences needed for graduate employability.

We did have a careers service at Warwick which I did visit but without much of a focus. I ended up being unemployed for a year after my degree and in some ways built up my own employability skills and competences during that year while I decided what I wanted to do. I developed my skills of working with children and young people while working voluntarily as a playgroup leader and youth worker as well as doing a job placement at a centre training community workers. These 
varied work experiences helped me to decide what I wanted my future employment to be. After this year I went back to Warwick University to train as a secondary school teacher and worked in school education for 14 years.

In contrast to then many universities now employ a range of strategies in relation to employability and view this as being part of their role. These include embedding employability skills within the curriculum and some subject areas lend themselves to this more than others; as extra-curricular activities and through one strategy which is now becoming popular - work placements or internships either as part of the curriculum or as an activity undertaken during non-term time. Other approaches include entrepreneurship modules, careers advice and activities, portfolios, profiles and records of achievement. However, Little claims that "while there is international concern that higher education should enhance graduate employability, there is little evidence of systematic thinking about how best to do it' (2003: 4).

As stated employers are increasingly looking for graduates who possess 'soft skills' such as 'high levels of communication, presentation, teamworking and written skills' (Andrews \& Higson, 2014: 277). University teaching is now increasingly incorporating group work and student presentations in their sessions and sometimes as part of the assessment process. An EC study - The Employability of Higher Education Graduates: the Employers' Perspective - by Humburg et al (2013) showed that employers considered interpersonal skills to be just as important as professional knowledge:

In order to be employable, a graduate needs interpersonal skills and below average levels cannot be compensated for - even by the best grades or the most relevant study field. This is because employers fear that potential negative consequences of poor interpersonal skills on the team as a whole and thus the impact on organisational goals (Humburg et al, 2013: v).

It is important when devising employment strategies to listen to the voices of students and take into account what they perceive to be important for their needs. Biographical interviews could be undertaken with both undergraduates and graduates who have entered the labour market to produce a handbook for university staff and employers identifying strategies based on the experiences and voices of students.

Work experience and internships are now seen as an important route into graduate employment. Helyer and Lee (2014) argue that work-based learning is beneficial to universities as well as it encourages 
students to develop experiential learning approaches and bring these attributes to their degree learning. Birchall feels that students are narrow learners if they focus only on their academic learning:

Students who just focus on their degree studies without spending time in the workplace are unlikely to develop the skills and interests that graduate employers are looking for (2013).

There is evidence to suggest that work placements are advantageous to students because employers are using them as a recruitment strategy. This is increasingly the case for those who undertake internships. Internships according to Guile and Lahiff support graduates in:

Developing expertise (knowledge, skill and judgement) and identity, but also helping to develop a) entrepreneurial flair so they can assist a business to grow; and b) social capital, that is, the networks to help them to secure permanent/contract-based employment or self-employment $(2013 ; 3)$.

Allen, Quinn, Hollingworth and Rose (2013), however, drawing on their qualitative study, are less positive about work placements as they argue that:

what makes a 'successful' and 'employable' student and 'ideal' creative worker are implicitly classed, raced and gendered. We argue that work placements operate as a key domain in which inequalities within both higher education and the graduate labour market are (re) produced and sustained (Allen et al., 2013: 431).

In their study students were left to find their own work placements which were unpaid. This advantaged middle class students because of their greater social and economic capital. To overcome issues of inequality Allen et al (2013) produced toolkits for both students and HE staff which offer guidance and recommendations for addressing inequalities. They also advocate financial support for working class students. A recent report by the Sutton Trust, UK indicates that unpaid internships favour the rich. The report goes on to say that' because these areas are so competitive, employers are often able to offer internships as completely unpaid positions. These issues make unpaid interships a serious and pressing problem for social mobility'.

Often students are expected to undertake work placements or internships during the holiday period. This penalises non-traditional students, particularly adult students with families as they have to either 
look after children as they cannot afford childcare or have to earn money in low skilled jobs. There are some exceptions to this. For example, Teeside University in the north east of England initiated in 2011-2012 the 'Graduate Internship Programme' which consists of a 12 week paid workexperience placement with a local employer. Importantly, besides being paid it is embedded within the students' development days at the university. Teeside is a post 1992 university with a commitment to widening participation and as a result has a diverse student population $66 \%$ are adult students. Part of the aim of the internship is also to boost the number of graduate level jobs and retain their graduates in the locality. The majority of the students and employers were positive about the experience. In particular the students liked the fact that the work related to their degree studies. Heyler and Lee maintain that: 'Facilitating undergraduate internships can work as part of developing students into resourceful change agents, who work across the business university interface to genuinely transfer and create knowledge' (2014: 367). Billett (2011) views workplace learning as being valuable for generating the 'power' of experiential learning and several studies show that students had become experiential learners (Heyler \& Lee, 2014). Students interviewed in a study by Andrews and Higson revealed that:

From the graduates' perspectives, experiential and work-based learning afforded multiple benefits allowing them to apply and hone theoretical skills learnt in education to 'real-life' ... workbased learning was that such experiences enhanced subsequent university-based learning (2014: 278-279).

Another study by Cranmer (2006) found that where universities combined work placement with employer involvement in the design of the curriculum positive outcomes were generated in relation to the capability of students to find graduate level jobs within six months after leaving university. The EC study by Humburg et al (2013) also indicates that when students engage in relevant work experience they are more likely to be offered a job interview and that work experience can compensate for having lower grades.

The UK government introduced a new degree initiative in 2001 entitled Foundation Degree to enhance vocational learning in higher education. The degree combines academic study with vocational learning (theory and practice) and students spend part of their degree course in a workplace setting. It is a qualification in itself - equivalent to two-thirds of a degree but all universities who have such programmes have to offer an Honours top-up route for students if they want to continue. It is aimed at people who are already working in a particular job or profession who want to improve their skill levels or at people who 
want to enter that work area. It is also part of the widening participation agenda. The curriculum has to be designed in collaboration with employers and with their support. A full-time Foundation Degree takes two years to complete. My department has a FD in Early Childhood Studies. Previously we had one on Community Enterprise and Development which I co-ordinated.

I am going to draw on some examples of practice from my institution to give a flavour of what is happening in universities but I am not saying that they are best practice or the only forms of practice. However, it does give an example of how being at an elite university enhances a graduates' chances of employment. Within six months of graduating 2010/2011 80\% of Warwick's undergraduates were in graduate employment and further study while at postgraduate level it was $89 \%$.

Within my department - Centre for Lifelong Learning - we have recently introduced new modules with the aim of improving the employability skills of our non-traditional adult students. Biographical research l've undertaken on the learning experiences of our adult students indicates that they do not think about employment possibilities when they start our 2+2 Social Studies or part-time degrees. The reasons they give instead for doing a degree is for self-development, with women to do something for themselves or to complete their education as they left school early. Some during their final year begin to think that they could do something in terms of a job but many do not think about it until after they've finished their degree. These new modules may help them to think more positively about future employment.

With the Research Placement module students undertake a work placement in the lifelong learning sector, for example, a college, prison, community education centre. Students have to choose and identify their own work placement setting which may be paid or unpaid. They have to undertake a small scale piece of research in the work setting and apply concepts and theories learnt in other modules. Other workbased vocational modules include coaching, mentoring and career development and career emplyability. This module encourages students to become a reflective practitioner through an introduction to coaching. The Teaching, Learning and Assessment in Lifelong Learning module provides an introduction to teaching in the post 16 Further Education and Skills sector and combines theory, research and practice.

http://www2.warwick.ac.uk/study/cll/othercourses/careerstudies/ currentstudents/cdcs/careeremployability 
Like most universities all departments including those which are not traditionally employment linked such as History, Politics, English have to address, in some way, issues relating to employability. There are also initiatives run centrally by the University such as the Warwick Advantage Award run jointly with the Students Union. This award helps students to identify their skills through a series of activities by asking:

Where do I start?

Where do I want to be?

What do I have to offer?

http://www2.warwick.ac.uk/services/scs/career/developingself/

The Student Careers and Skills Services also have an activity to help students develop an Employability Development profile.

\section{http://www2.warwick.ac.uk/study/undergraduate/employability}

These are not exhaustive examples.

\section{CONCLUSION}

Employability is now firmly part of the agenda of European universities and a closer link and engagement between universities and the employment sector is a by-product of this, Universities, national governments and the EU all agree that it is a good thing to develop the employability skills and competencies of their students. While there is some evidence of good policy and practice there is still a long way to go in achieving this across the system as a whole. At present we have an unequal system whereby some graduates are at an advantage because of their class, gender and ethnic backgrounds and cultural and social capitals so that the white middle class male is more likely to end up the most prestigious and well paid graduate jobs. Surveys show, for example, that women earn less.

Universities and employers need to address the inequalities issue as at the moment the odds are stacked in favour of those who go to a top or elite university, and as stated above, are white, male, middle class, and are younger rather than older. Research which listens to the voices of a diverse range of students is needed in order to understand the issues and problems from their perspectives. Work placements and internships, for example, should be accessible to all those who want to participate so that those on low income are not disadvantaged. 

about?

And finally there are also some key questions to ask and think

Who is benefitting from employability schemes and strategies? Employers or students?

Are we also asking too much of students? Not only do they have to do their subject degree studies but also there is the onus on them to develop their employability skills and portfolio if they want to succeed in a competitive, individualistic world.

\section{REFERENCES}

Andrews, J, and Higson, $\mathrm{H}$ (2014), Is Bologna Working? Employer and Graduate Reflections of the Quality, Value and relevance of business and Management Education in four European Union Countries, Higher Education Quarterly, 8 (3), pp267-287

DOl: http://dx.doi.org/10.1111/hequ.12054

Allen, K., Quinn, J., Hollingworth, S. and Rose., A (2013) Becoming employable students and 'ideal' creative workers: exclusion and inequality in higher education work placements, British Journal of Sociology of Education, 34 (3), pp 431- 452

DOI: $\mathrm{http} / / / d x . d o i . o r g / 10.1080 / 01425692.2012 .714249$

Archer, W. and Davison, J. (2008) Graduate Employability: What do employers think and want? The Council for Industry and Higher Education, http://www.eihe=uk.com

Barnett, R. (2007). A will to learn: Being a student in an age of uncertainty, Maidenhead,

Open University Press / McGraw- Hill Education.

Beck, U (1992), Risk Society: Towards a New Modernity, London, Sage

Billett, S (2011) Curriculum and Pedagogic Cases for Effectively Integrating Practice-Based Experiences, Sydney, Australian Learning and Teaching Council

Birchall, M (2013) in Coughlan, S Job Advantage for Graduates with Work Experience - - Survey, http://www.bbc.co.uk/news/education=22873717

Blackmore, J. and Sachs, J. (2003) Zealotry or nostalgic regret? Women leaders in technical and further education in Australia: Agents of change, entrepreneurial educators or corporate citizens? Gender, Work and Organization 10, pp478-503

DOI: http://dx.doi.org/10.1111/1468-0432.00207

Brown, P, Hesketh, A and Williams, S (2002) Employability in a KnowledgeDriven Economy, Working Paper Series, Paper 26 Cardiff University 
Brown, P and Scase, R, (1994) Higher Education and Corporate Realities: Class, cultures and the decline of graduate careers, London, $\mathrm{UCL}$ Press

Kalfa, S and Taksa, L (2013) Cultural capital in business higher education: reconsidering the graduate attributes movement and the focus on employability, Studies in Higher Education.

DOI: http://dx.doi.org/10.1080/03075079.2013.842210

Castells, M (2001) The University System: engine of development in the new world economy,

Paper presented at the World Bank Seminar on Higher Education and Development, Kuala Lumpar

Clarke, M (2008), Understanding and managing employability in changing career contexts, Journal of European Industrial Training, 32 (4), pp. 258-284.

DOI: http://dx.doi.org/10.1108/03090590810871379

Confederation of British Industry (2012) Boosting Employability Skills,

Cranmer, S. (2006) Enhancing graduate employability: best intentions and mixed outcomes, Studies in Higher Education, 31 (2), pp 169184. DOI: $\mathrm{http}: / / \mathrm{dx} . \mathrm{doi} . \mathrm{org} / 10.1080 / 03075070600572041$

Cumming, J. (2010) Contextualised performance: Reframing the skills debate in research education, Studies in Higher Education, 1-15 ifirst article

Edvardsson Stiwne, E and Gaio Alves, M (2010) Higher education and Employability of Graduates: will Bolgna make a difference? 9 (1), pp32-44

Guile, D. and Lahiff, A. (2013) Internship: Conventional Wisdom, Models \& Recommendations, London, London Institute of Education, University of London

Helyer, R and Lee, D (2014) The Role of Work Experience in the Future Employability of Higher Education Graduates, Higher Education Quarterly, 68 (3), pp 349-372

DOI: http://dx.doi.org/10.1111/hequ.12055

Hugh-Jones, S, Sutherland, E and Cross, A (2006) The graduate: Are we giving employers what they want? Paper presented at the Teaching and learning Conference, January, 6, Leeds

Hyslop -Marginson, E. J. and Sears, A. M. (2006), Neo-liberalism, globalisation and human capital learning, Dordrecht, Springer

Humburg, M., van der Velden, R., and Verhagen, A. (2013) The Employability of Higher Education Graduates: The Employers' Perspective, European Commission

Gumport, P (2000) 'Academic restructuring; organizational change and institutional imperative', Higher Education, 39, pp 67-91

Holmes, L (2013) Competing perspectives on graduate employability: possession, position or process? Studies in Higher education, 38 (40, pp538-554 
Lave, J \& Wenger, E. C. (1991) Situated Learning: legitimate peripheral participation, Cambridge, Cambridge University Press

DOI: http://dx.doi.org/10.1017/CBO9780511815355

Leonard, D (2000) Transforming doctoral studies: Competences and artistry, Higher Education in Europe, 25, pp 181-192

DOI: http://dx.doi.org/10.1080/713669254

Little, B (2003) International perspectives on Employability, Briefing Paper, York, The Higher Edcuation Academy,

Merrill, B, (2012), Learning to become an Adult Student: Experiences in a UK university in International Journal of Continuing Education and Lifelong Learning, Vol.5 Issue 1 (November), pp21-42

Moreau, M. P. and Leathwood, C (2006), 'Graduates' employment and discourse of employability; A critical perspective, Journal of Education and Work, 14 (4), pp305-324

DOI: http://dx.doi.org/10.1080/13639080600867083

Reay, D. 2003, A Risky Business? Mature Working-class Women Students and Access to Higher Education, Gender and Education, 15, no. 3: $301-317$.

DOI: http://dx.doi.org/10.1080/09540250303860

Redmond, P. (2006) Outcasts on the Inside: Recent Graduates, Employability and Widening Participation, Tertiary Education and Management, 12, pp 119-135

DOI: $\underline{\text { http://dx.doi.org/10.1080/13583883.2006.9967163 }}$

Scott, P (2005) 'Universities and the knowledge economy, Minerva, 43 (3), pp 297-309. DOI: http://dx.doi.org/10.1007/s1 1024-005-6510-4

Smith, J., McKnight, A. and Naylor, R. (2000) Graduate Employability: 'Policy and performance in Higher Education in the UK, The Economic Journal, 110, pp382-41 1

DOI: http://dx.doi.org/10.1111/1468-0297.00546

Tomlinson, M (2012), Graduate Employability: A Review of Conceptual and Theoretical Themes, Higher Education Policy, 25, pp 412-431

Tomlinson, M (2008) The degree is not enough: Students' perception of the role of higher education credentials for graduate work and employability, British Journal of Sociology of Education, 29 (1), pp49-61. DOI: http://dx.doi.org/10.1080/01425690701737457

Tymon, A (2013) The student perspective on employability, Studies in Higher Education, 38 (6), pp841-856

DOI: http://dx.doi.org/10.1080/03075079.2011.604408

Yorke, $M$ (2004) Employability in the undergraduate curriculum. Some student perspectives, European Journal of Education, 39 (4), pp409-427. DOI: http://dx.doi.org/10.1111/j.1465-3435.2004.00194.x 


\section{Sobre el autor:}

Barbara Merrill

Barbara.Merrill@warwick.ac.uk

La Dr. Barbara Merrill es profesora del Centre for Lifelong Learning de la University of Warwick (Reino Unido). Sus intereses de investigación incluyen temas tales como la experiencia de los estudiantes adultos en la enseñanza superior, la educación de la comunidad, género, educación de adultos, investigación biográfica narrativa y educación de adultos, problemas de acceso, permanencia y abandono, así como estudio de las experiencias de aprendizaje y la identidad del estudiante en la Enseñanza Superior.

\section{Para citar este artículo:}

Merrill, B. (2015). Strategies of action: improving employability. Revista Fuentes, 16, Junio, pp. 15-36. [Fecha de consulta: dd/mm/aaaa]. http://www.revistafuentes.es/

D.O.I.: http://dx.doi.org/10.12795/revistafuentes.2015.i16.01 